\title{
Anmeldelser
}

Tips om medisinsk litteratur, andre bøker, filmer og elektroniske medier som bør anmeldes, sendes tidsskriftet@legeforeningen.no

\section{Om å lykkes som medisinstudent}

Evans D, Brown J.

How to succeed at medical school

An essential guide to learning. 179 s, tab, ill. Chichester: Wiley-Blackwell, 2009. Pris GBP 15 ISBN 978-1-4051-5139-9

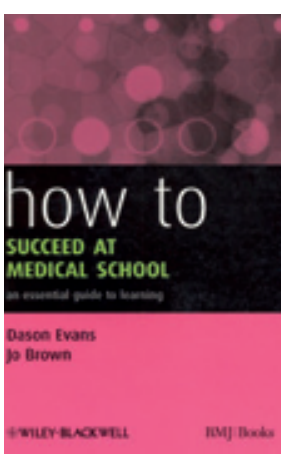

Forfatterne har $i$ årevis vært engasjert i utdanningen av medisinstudenter i Storbritannia. De har observert hvor mange studenter som sliter med å klare seg på en adekvat måte gjennom medisinstudiet. En god del av våre studenter gjør også det. Forfatternes hovedhypotese er at dette bl.a. skyldes at studentene ikke i tilstrekkelig grad er seg bevisst at de i studiet selv må være meget aktive i å identifisere sine læringsmål og forfølge disse. Den enkelte student er altfor lite klar over sin spesifikke læringsstil, og er usikker på forskjellen mellom å skulle lære kunnskaper og å skulle lære seg kliniske ferdigheter. De undervurderer dessuten betydningen av å sette seg sine egne læringsmål og evaluere sin egen fremgang. Hvilken utfordring studenten står overfor ved starten på medisinutdanningen i forhold til på videregående skole, oppsummeres slik:

«In medicine you will not get taught everything you need to know, and yet you will still be expected to learn it - to work out what you need to learn, to work out ways of learning it, to work out ways of knowing when you have learnt it, and to get on and learn it»

I korte kapitler gis det konkrete råd om hvordan studenten kan forbedre sin læring. Det er kapitler om å finne sin læringsstil, om måter å bedre identifisere hva som det er viktig å lære av kunnskaper og ferdigheter, om hvordan man bedre kan skaffe seg disse kunnskapene og kliniske ferdighetene, om å trene på kommunikasjonsferdigheter, om å lære bedre i grupper, om å skrive gode oppgaver, om mappeevaluering, om å reflektere over sine mål og sin læring, om å balansere studiet og fritiden, om å repetere sine kunnskaper på en effektiv måte, og om å håndtere eksamensnerver.
Stilen er kortfattet og typisk britisk i sine «understatements». Boken er ikke tykk, men må leses langsomt. Den er selvsagt også noe preget av at forfatternes erfaringer er fra studier i Storbritannia. Men det meste av stoffet er høyst relevant for våre studenter. De fleste medisinstudenter vil nok finne noe av interesse som kan gjøre livet som student mer engasjerende og mer overkommelig. Boken reiser for meg et viktig spørsmål: I hvilken grad bør våre medisinske fakulteter eksplisitt og systematisk gi denne type pedagogisk innføring i å studere medisin?

\section{Per J. Wiggen Vaglum}

Avdeling for medisinske atferdsfag

Universitetet i Oslo

\section{0 år og «still going strong»}

\section{Standring S, red}

\section{Gray's Anatomy}

The anatomical basis of clinical practice. 40. utg. 1576 s, tab, ill. London: Churchill Livingston Elsevier, 2008. Pris USD 199 ISBN 978-0-443-06684-9

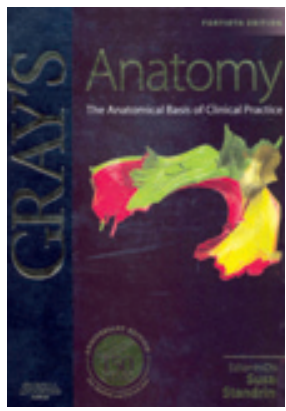

Hvis noen bok fortjener betegnelsen klassiker, må det vel være Gray's Anatomy - nå i sin 40. utgave. Denne utgaven beholder formatet og siktemålet fra tidligere, men er ellers gjennomarbeidet og modernisert. Ikke minst er illustrasjonsmaterialet fornyet og harmonisert med hensyn til stil og fargevalg. Det er også lagt betydelig omtanke i å gjøre illustrasjonene poengtert uten å gå for mye på akkord med anatomisk nøyaktighet.

De ni seksjonene har titler som «Cells, tissues and systems», «Embryogenesis», «Neuroanatomy», «Pectoral girdle and upper limb», «Abdomen and pelvis» osv. Det er altså i hovedsak en regional - ikke en systematisk inndeling. I hver seksjon er det omtale av organenes utvikling, og mange, velvalgte kliniske poenger. Stoffet dekker anatomien i vid og moderne forstand - fra makroanatomi ned til molekylæranatomi. Histologi, makroskopisk anatomi og relevant fysiologi integreres på en utmerket måte. Illustrasjonene er både estetisk og didaktisk meget vellykkede. Til tross for størrelsen er det er lett å finne det man leter etter, både fordi innholdet er logisk oppbygd og fordi fargekoder på sidene hjelper leseren på rett vei. Det finnes også et meget fyldig register som virker imponerende gjennomarbeidet - det er ikke bare den etter hvert så vanlige elektronisk genererte indeks uten tilstrekkelig faglig medvirkning. Her er hovedord i fete typer, og to nivåer under sikrer at det blir begrenset antall oppslag for hvert stikkord. Kjøp av boken gir adgang til nettstedet «Expert Consult» hvor blant annet hele boken finnes i lett søkbar form, og hvor illustrasjoner kan hentes ut til bruk i egen undervisning. Bokens største ulempe er størrelsen og vekten.

Dette er en bok man går til med forventning om å finne pålitelig, kritisk vurdert og oppdatert informasjon. Kvalitetssikring av innholdet er blant annet skjedd ved bruk av en egen redaktør for hver seksjon, spesialistforfattere og et stort antall nasjonale og internasjonale konsulenter. Mitt inntrykk etter å ha oppsøkt områder hvor jeg selv har relativt god kunnskap, er at boken innfrir forventningene om pålitelighet. Mine stikkprøver tyder på at forfatterne har greid å kombinere didaktisk klare fremstillinger med nødvendige forbehold og påpekning av usikkerhet og manglende kunnskap. Jeg stusser likevel litt over at referansene etter hvert kapittel som regel er få og tilsynelatende nokså tilfeldige.

Hvem er målgruppen? Undervisere med behov for pålitelige anatomikunnskaper er én åpenbar gruppe. Videre henvender boken seg også til - og bør være velegnet for klinikere innen de fleste fag. For medisinstudenter er den altfor omfattende som lærebok, men kan være nyttig som oppslagsbok på spesielle områder. Den bør selvfølgelig finnes i helsefaglige biblioteker.

Alt $i$ alt er jeg imponert over denne nye utgaven av Gray's. Den viser hva som kan komme ut av en heldig blanding av et ressurssterkt forlag med vilje til å satse på faglig kvalitet, en hovedredaktør med visjoner og (tror jeg) bein i nesa, og mange engasjerte fagfolk som er villige til trekke i samme retning.

\section{Per Brodal}

Avdeling for anatomi

Institutt for medisinske basalfag

Universitetet i Oslo 